\author{
Marek Zvelebila †', Malcolm C. Lillie ${ }^{b, *}$, Janet Montgomeryc, Alena Lukes ${ }^{d}$, \\ Paul Pettitta, Mike P. Richardse
}

\title{
The emergence of the LBK: Migration, memory and meaning at the transition to agriculture
}

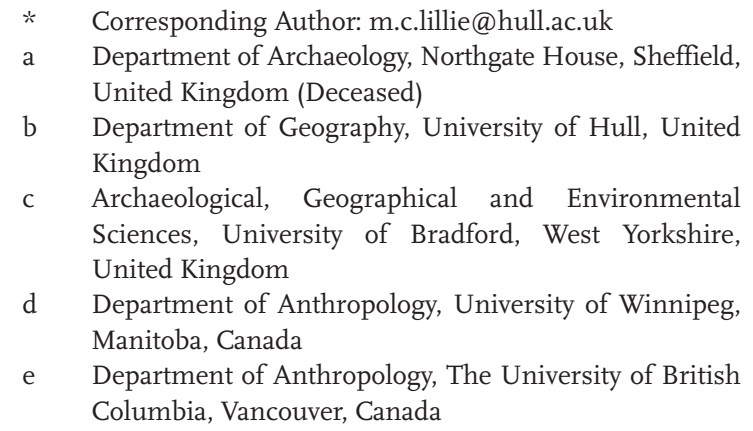

Dedication: This paper is dedicated to the memory of the first author, Professor Marek Zvelebil who died unexpectedly on the 7 th July 201 in aged 59. For over 30 years Marek was a leading figure in archaeology, and internationally he was widely regarded as being among the most important and influential archaeological thinkers of his generation. Marek was a consummate intellectual who lived life to the full, he was a mentor, friend and inspiration to many in a generation of archaeologists, he will be sorely missed.

\begin{abstract}
This paper represents one element of a collaborative research project, funded by the AHRC, which focussed on a multidisciplinary study of the Earlier Neolithic cemetery of Vedrovice, Moravia, Czech Republic. One of the key aims of this project was the generation of new knowledge in relation to the emergence of the Linear Pottery, or Linearbandkeramik (LBK) culture in Europe. The current paper focuses on the evidence for the shift from hunting and gathering to farming from the perspective of individual life histories and the transmission of knowledge through migration and cultural exchanges.
\end{abstract}

\section{Keywords}

Linearbandkeramik (LBK), Bioarchaeology, Neolithic, Strontium, aDNA, Migration, Cultural transition

\section{Introduction}

The Linearbandkeramik Culture (LBK) is central to current debate concerning the origins and spread of agriculture in Europe (e.g. Lukes and Zvelebil, 2006; Lüning, I988; Modderman, I988; Zvelebil et al., 2008). Despite earlier assertions that this culture represented an homogenous entity, reflecting a rapid east-west colonization event, recent research has increasingly highlighted significant local and regional diversity in the material culture inventories and subsistence strategies of the individual groups (e.g., Bánffy, 2004; Gronenborn, I999, 2003, 2004; Lukes, 2004, 2006; Lukes and Zvelebil, 2004; Mateiciucová, 2004; Price, 2000; Rulf, I995, I997; Whittle, I996; Zvelebil, 2000a, 2000b, 2004; Zvelebil et al., 2008). The diversity, as identified, has in many cases been interpreted as representing continuity in indigenous lifeways and the integration of indigenous hunter-forager material culture and world views into the LBK, as various elements of food-production economies are transmitted into Europe.

In order to begin to generate meaningful narratives addressing the role of indigenous groups within the LBK we began our research at the site level. This focus allows us to consider a single community at a single site where individuals actively engaged with the materiality of life in the daily cycle of practice and negotiation of identity. Their activities were undertaken in accordance with both individual and communal motives (as per the concepts of agency, habitus and practice discussed elsewhere by Barrett [i994, 
I997], Bourdieu [1977, I990], Dobres and Robb [2000], Giddens [1979, I984], Hodder [1992, 2000], and Shanks and Tilley [I992]) (Lukes et al., 2008). One of the advantages of this site-level focus is that it enables us to explore how individual identities are constructed (and/or deconstructed/reconstructed) through the memories and learned experiences that are bound up in established socio-political traditions.

From this initial perspective, the current paper will inform the key debates in relation to the three main approaches used to model the emergence of the LBK culture:

- Migrationist models, which highlight the role of incoming colonists (Cavalli-Sforza and CavalliSforza, I995; Childe, I957; Piggott, I965; van Andel and Runnels, I995; Vencl, I986);

- Indigenist models, which focus on the role of local indigenous groups (Barker, I985; Dennell, I983; Pluciennik, I998; Tilley, I994; Whittle, I996);

- Integrationist models, which explore the interaction of both population groups (Chapman, I994; Price, I987; Renfrew, 1996; Zvelebil, I986, I995, 1996).

In outlining the nature of social interaction, participation and the intergenerational transmission of knowledge at the Mesolithic-Neolithic transition, the above models allow for the understanding of the LBK at the communal level through the identification of the intergenerational transmission and acquisition of knowledge. This transmission/acquisition is, to some degree, structured and motivated by social context as expressed through variation in stylistic elements of material culture (Lukes et al., 2008). As such, whilst the focus of the research reported here is on the evidence for migration at the Vedrovice cemetery/settlement, the overarching research agenda comprises an examination of personal biographies and communal identity derived from the application of bioarchaeological analyses to human and material remains (e.g. Lillie, 2008; Lukes et al., 2008; Richards et al., 2008; Smrčka et al., 2005, 2008; Zvelebil and Pettitt, 2008). By generating information aimed at elucidating personal biographies, through the use of bioarchaeology, AMS dating and isotopic studies, we are able to identify those individuals who were indigenous to the region and those who had migrated into the region, and ascertain which individuals might be considered as having had the fundamental knowledge essential for the development of food production strategies.

\section{The site}

The site that forms the basis for the current study is Vedrovice, Moravia in the Czech Republic (Fig. I). This site has two key earlier Neolithic components: a settlement featuring traces of the materiality of daily life (Podborský, I993, 2002; Čižmář, 2002) and the focus of the current study, which is a cemetery that has produced one of the largest collections of Neolithic human remains in Central Europe (Podborský, 2002). Fortunately there are well-documented records of the material culture for both the cemetery and settlement site. Vedrovice is located in southern Moravia in the southeastern part of the Czech Republic, near Moravský Krumlov in the Znojmo district (Ondruš 2002).

The inhumations in the Široká u Lesa cemetery at Vedrovice were deposited over the course of the $53^{\text {rd }}$ century BC, possibly continuing a little into the early $52^{\text {nd }}$ century BC, a period spanning five or six generations (Pettitt and Hedges, 2008). In the wider context Vedrovice falls within the middle LBK Flomborn phase, which saw a major expansion of the LBK into Central Europe (Gronenborn, I999; Price et al., 200I). To a certain extent then, the Vedrovice community can be seen as a pioneer in the region, existing as it did at a time when agriculture was newly established in Central Europe. 


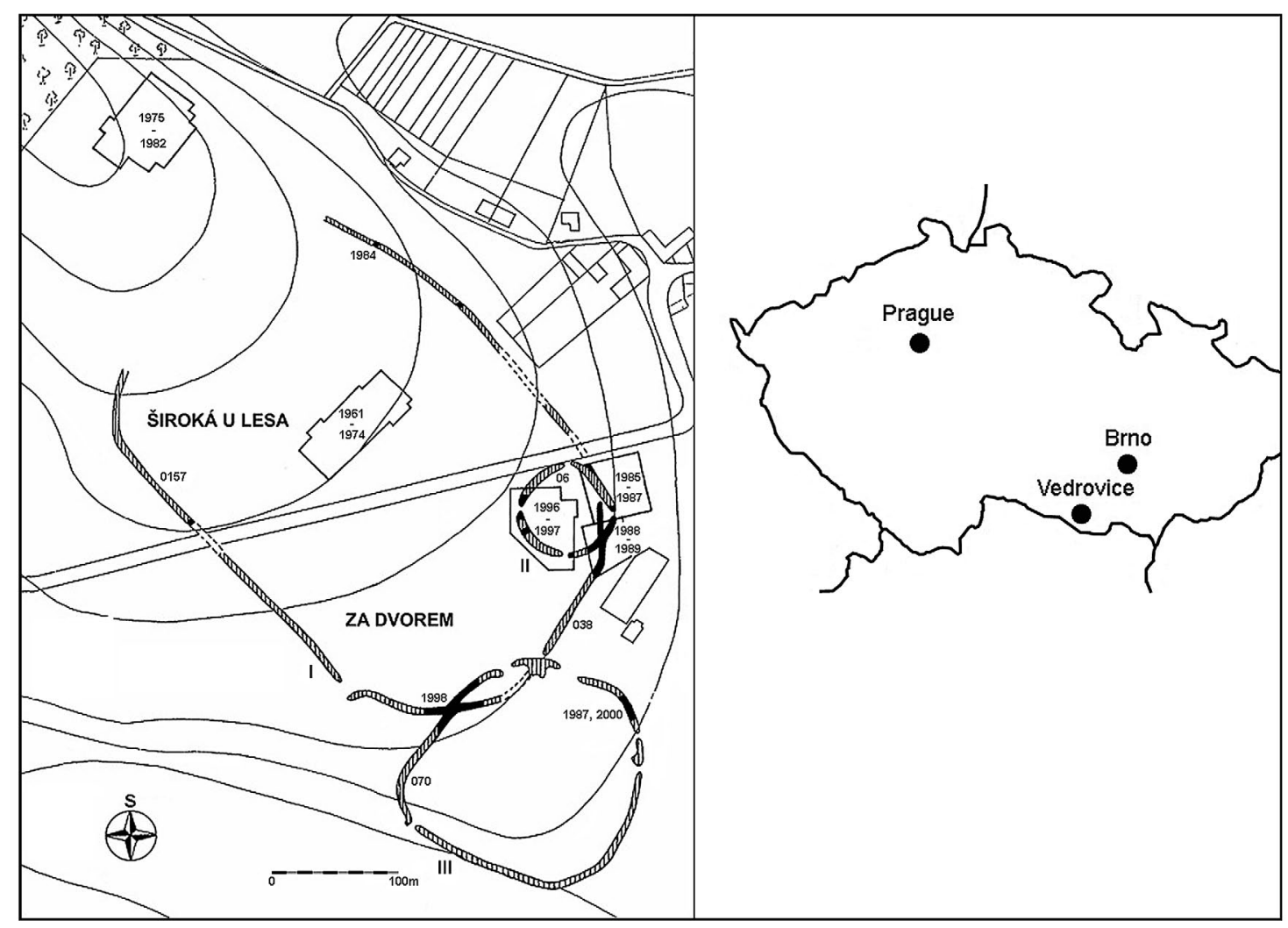

Fig. 1 | Map showing the location of Vedrovice in the Czech Republic (right side) and the Neolithic sites at Vedrovice (left side) as identified between I96I and 2000 (based on Ondruš in Podborský [2002]). The main cemetery (I) is located to the top left side of the plan in the area Široká u lesa, whilst indications of settlement and ca. 22 Neolithic burials were recovered between the Cigth and the I950s in the area Za dvorem (centre and right side of map). Between I96I and I989, an LBK settlement of ca. $5000 \mathrm{~m}^{2}$ was investigated in the area of Šroká u lesa by the archaeology department of the Moravian Museum in Brno

The material culture inventory and skeletal collection from Vedrovice includes ceramic vessels, miniature vessels, weights, drilled ceramic disks and figurine fragments, post holes from housing structures, pits, ovens, flaked and polished stone tools, grinding stones, faunal remains and bone tools (Berkovec, 2003; Berkovec and Veselá, 2003-2004; Berkovec et al., 2004; Humpolová, 2001; Humpolová and Ondruš, I999; Ondruš, 2002; Podborský, 2002; Lukes, 2006). In addition, there are ca. 8I individuals interred in the Neolithic Široká u Lesa cemetery, and a further 23 burials from the Neolithic settlement (Podborský, 2002; Crubézy et al., I997; Smrčka et al., 2005; Lillie, 2008).

In general the material from the cemetery has a much greater degree of preservation and smaller frequency of fragmentation than does that of the settlement site, yielding, for instance, a higher percentage of intact vessels (Čižmář, 2002; Lukes, 2006). Furthermore, differences in the composition and type of the material culture inventory between the cemetery and settlement have been identified, leading to the suggestion that "the world of the living had been kept separate from the world of the dead" (Berkovec et al., 2004). Hence, individual burials provide a unique opportunity to apply objective bioarchaeological approaches, supplemented by material culture in the form of grave goods, in order to construct individual biographies that facilitate an exploration of the nature of individual identity in contrast to the communal identity that is evident at the settlement. 


\section{Methodology}

\section{Sulphur isotope analysis}

In the original research programme, sulphur isotope analysis was carried out on the collagen of 50 individuals from the Vedrovice cemetery (Richards et al., 2008). This method requires that large amounts of collagen be available for analysis, as Richards et al. (200I, I86) have noted that previous work on archaeological and palaeontological bone has been limited by the difficulty of measurement, as bone collagen contains very little sulphur (0.16 wt\%, calculated from amino acid composition). Furthermore these authors have also noted that the collagen becomes increasingly chemically degraded over time. The methodology for the measurement of sulphur isotopes in the bone collagen followed that of Richards and colleagues (200I, 2003). Sulphur isotopes are somewhat indicative of diet, but are most useful in determining the geographical location in which the individual resided during formation of the collagen. Collagen is formed over the preceding one to two decades, yielding values reflecting fairly recent locations (compared to strontium, discussed in the next paragraph). In general sulphur isotope values vary between about -20 and +20 per mil, i.e., a total range of about 40 per mil; in the recent study at Vedrovice the data generated indicated clustering around the value of $o$, with a range of -2 to +2 . This is consistent with Vedrovice's location in central Europe (Richards et al., 20II).

\section{Strontium isotope analysis}

We measured the strontium isotope ratios and concentrations in tooth enamel; these values reflect the geological location where the individual spends his or her childhood, when their enamel is formed (Price et al., 2002). Unlike bone, enamel, once formed, is not remodelled and, unlike bone and dentine, it is highly resistant to postmortem diagenesis (Budd et al., 2000; Hoppe et al., 2003; Trickett et al., 2003). Therefore strontium isotope values for enamel tell us whether adult individuals spent their childhoods in locations other than those at which they were eventually buried as adults (Richards et al., 2008).

The methodology used for the analysis of strontium isotopes followed that outlined by Richards and colleagues (2008). Twenty-two individuals from Vedrovice were investigated during this stage of the study. Three samples of the underlying crown dentine were obtained for use as proxies for the mobile soil strontium (Budd et al., 2000; Hoppe et al., 2003; Montgomery et al., 2007). Chemical separation and analysis of the enamel samples was undertaken at the Max Planck Institute for Evolutionary Anthropology, Leipzig, Germany, using plasma ionization multicollector mass spectrometry (PIMMS) following the methods outlined by Copeland and colleagues (2008). ${ }^{87} \mathrm{Sr} /{ }^{86} \mathrm{Sr}$ values measured for SRM987 (NIST international strontium carbonate isotope standard), which was analysed concurrently with the samples, were $0.71027 \pm 0.000015$ (Is, $\mathrm{n}=7$ ), which is well within its certified value of $0.71034 \pm 0.00026$.

\section{Results}

The results obtained from this stage of the analysis (Table I) have demonstrated that migration occurred in the population interred at Vedrovice. We will use the results presented below to evaluate the degree to which migration represents 'local' movements between groups/individuals in a discrete geographical 
Table 1 | Isotope ratios for twenty-two individuals at the Vedrovice cemetery, Czech Republic

\begin{tabular}{|c|c|c|c|c|c|c|c|c|c|c|c|}
\hline S-EV A & Individual & \%Coll & $\delta^{13} \mathrm{C}$ & $\delta^{15} \mathbf{N}$ & $\% \mathrm{C}$ & $\% \mathrm{~N}$ & C:N & $\% \mathrm{~S}$ & $\delta 34 \mathrm{~S}$ & ${ }^{87 / 86} \mathrm{Sr}$ & Sr ppm \\
\hline 3216 & I5/75 & 3.0 & $-I 9.2$ & I0.0 & 40.6 & I4.4 & $3 \cdot 3$ & 0.2 & $-O . I$ & 0.710847 & 7I \\
\hline 3215 & $\mathrm{I} 6 / 75$ & 6.I & -19.9 & $9 \cdot 7$ & $44 \cdot 3$ & $15 \cdot 9$ & 3.2 & 0.2 & $-\mathrm{I} .4$ & $0.7 I I I 50$ & 77 \\
\hline 1319 & $30 / 76$ & 2.4 & -19.5 & $9 \cdot 5$ & 32.2 & II.O & $3 \cdot 4$ & O.I & 2.6 & 0.710831 & 88 \\
\hline I300 & $38 / 76$ tooth & & & & & & & & & 0.710407 & I37 \\
\hline I308 & $42 / 77$ & I. 2 & -19.5 & 9.8 & 38.6 & I 4.0 & 3.2 & 0.2 & -I.I & O.7IIOII & II3 \\
\hline I320 & $43 / 77$ & 3.0 & -20.0 & $9 \cdot 7$ & 42.7 & I4.9 & $3 \cdot 4$ & 0.2 & I.I & $0.7 \mathrm{II} 242$ & 78 \\
\hline 3233 & $48 / 75$ & I. 5 & -19.8 & 10.3 & 37.0 & I2.9 & $3 \cdot 3$ & 0.2 & $-\mathrm{I} .2$ & 0.711032 & 82 \\
\hline 3240 & $5 \mathrm{I} / 77$ & 0.5 & -20.7 & $9 \cdot 5$ & 40.7 & II.7 & 4.0 & & & $0.709 \mathrm{II} 2$ & I90 \\
\hline 3237 & $54 / 78$ & 6.5 & -19.6 & IO.I & 44.2 & $\mathrm{I} 5 \cdot 4$ & $3 \cdot 3$ & 0.2 & 0.8 & 0.711092 & 58 \\
\hline I3O2 & $59 / 78$ & 0.7 & -19.4 & I0.3 & 27.8 & 9.8 & $3 \cdot 3$ & & & 0.7II44I & IO9 \\
\hline 1309 & $62 / 78$ & I.O & -19.9 & $9 \cdot 4$ & 36.2 & $\mathrm{I} 2.7$ & $3 \cdot 3$ & 0.2 & -0.3 & $0.7 \mathrm{II} 293$ & I27 \\
\hline $40 I I$ & $66 / 70$ & & $\mathbf{n} / \mathbf{a}$ & & & & & & & 0.711529 & IO4 \\
\hline $32 \mathrm{I7}$ & $73 / 79$ & $4 \cdot 9$ & -19.7 & 10.2 & $43 \cdot 9$ & I5.5 & $3 \cdot 3$ & 0.2 & I. 8 & 0.711009 & 75 \\
\hline 3239 & $75 / 79$ & $4 \cdot 3$ & -19.5 & $9 \cdot 3$ & $44 \cdot 7$ & I5.3 & $3 \cdot 4$ & 0.2 & 0.9 & 0.7III77 & II9 \\
\hline 3219 & $79 / 79$ & 3.9 & -19.6 & 10.0 & 43.7 & I5.7 & $3 \cdot 3$ & 0.2 & $-3 \cdot 4$ & 0.709852 & 202 \\
\hline 3218 & $82 / 79$ & 3.8 & -I9.I & 10.6 & 42.0 & I5.I & 3.2 & 0.2 & -0.6 & $0.7 \mathrm{II} 33 \mathrm{I}$ & IOI \\
\hline 3222 & $84 / 80$ & 2.2 & -20.2 & 9.9 & 30.6 & 10.5 & 3.4 & 0.2 & $-\mathrm{I} .4$ & 0.7I097I & IOO \\
\hline 3235 & $93 a / 80$ & 3.6 & -19.8 & 10.2 & 4I. 6 & I 4.3 & $3 \cdot 4$ & 0.2 & 2.4 & 0.711515 & II9 \\
\hline 3244 & IO2/8I & $4 \cdot 4$ & -20.0 & 9.2 & $43 \cdot 6$ & I 5.5 & $3 \cdot 3$ & 0.2 & -0.2 & 0.712627 & IOI \\
\hline 3236 & I04/8I & 2.5 & -19.9 & 9.8 & $39 \cdot 5$ & I 3.4 & $3 \cdot 4$ & 0.2 & $-\mathrm{I} .5$ & $0.7 \mathrm{II} 2 \mathrm{OI}$ & 98 \\
\hline 3242 & I05/8I & $7 \cdot 3$ & -19.7 & 9.0 & $44 \cdot 9$ & I5.9 & $3 \cdot 3$ & 0.2 & $-O . I$ & $0.7 \mathrm{II} 30 \mathrm{I}$ & $9 \mathrm{I}$ \\
\hline 3238 & $107 / 82$ & 4.9 & -19.3 & 8.9 & $45 \cdot 4$ & I6.2 & $3 \cdot 3$ & 0.2 & I. 3 & 0.711373 & 49 \\
\hline
\end{tabular}

Fig. 2 | Strontium ratio and concen-

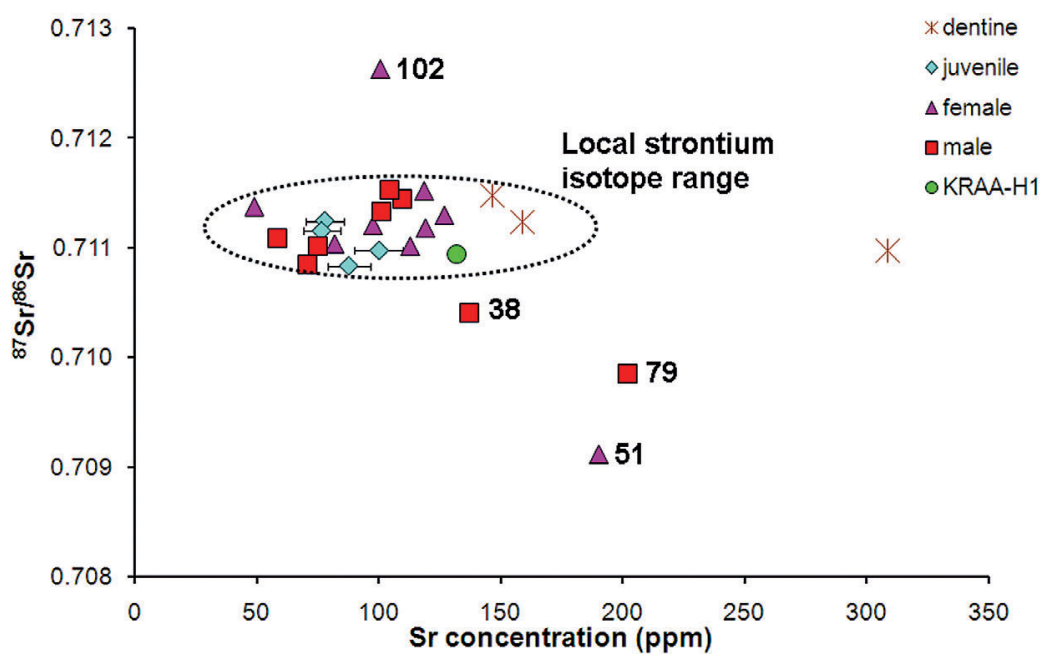


area or longer-distance migrations from a wider interregional context; we will also consider the material culture inventory of the cemetery population.

\section{Sulphur isotope analysis}

There is some evidence for variability in this population (Table I), with two adult males $(63 / 78$ and 95/80) and one adult female (I4/75) having S values higher than those of the others, and one adult male (79/79) and one adult female (IOI/8I) having S values that are lower than the others. The suggestion is that these individuals resided somewhere other than in Vedrovice during the last Io-20 years of their lives, although the absence of comparative data prevents further elucidation on this point (Richards et al., 2008).

\section{Strontuim isotope analysis}

In the current study, the enamel strontium concentrations have a mean equal to $105 \pm 36 \mathrm{ppm}$ Is and a range of 49-202 ppm, $n=23$. These are consistent with omnivorous humans in non-coastal, temperate Europe (Montgomery, 2002; Montgomery et al., 2007). Most of the individuals share a similar strontium isotope value: 18 of the 22 individuals analysed form a cluster with a strontium isotope range of $0.7108-0.7115$ and a mean equal to $0.7 \mathrm{II} 2 \pm 0.0002$ Is, $\mathrm{n}=\mathrm{I} 8$ (Table I and Fig. 2). This group includes all of the juveniles, and is co-incident with the range of dentine ratios indicative of local mobile strontium (Montgomery et al., 2007). The dentine range (0.7IIO-0.7II4) corresponds well with values of 0.7IIO-0.7II2 obtained for bone and dentine from the loess LBK site at Asparn-Schletz, in Lower Austria (Prohaska et al., 2002). It has been suggested that juveniles provide a useful way of estimating the range of local strontium values for a community as they would, potentially, have had much less time in which to undertake migration when compared to the adults (Evans and Tatham, 2004; Montgomery et al., 2005; Schutkowski, 2002).

There are some exceptions however. One female (IO2/8I) has a strontium isotope value higher than the majority of the others, and two males (38/76 and 79/79) and one female (51/77) have values lower than the majority, although the isotope ratio of individual number $38 / 76$ is close to the main Vedrovice cluster. These four individuals, who were buried in four different regions of the cemetery, appear to have spent part of their childhoods at a location other than Vedrovice. None of the values for these individuals are consistent with an origin in regions of geologically young rocks, such as recent volcanic basalts, or marine sediments, such as Cretaceous chalks (McArthur et al., 200I; Montgomery et al., 2005; Price et al., 2004). Neither do they result entirely from origins on Precambrian granites and gneisses of the Bohemian Massif, where strontium ratios from pigs have been found to exceed 0.7I8 (Bentley and Knipper, 2005). However, the female I02/8I has a strontium isotope ratio of 0.7I26, indicative of some dietary contribution from Palaeozoic or Precambrian rocks, which are found principally to the north and west in upland regions (Bentley and Knipper, 2005). The values for the two individuals with the lowest strontium isotope ratios (79/79 and 5I/77) are consistent with younger Mesozoic rocks, such as those found to the east and south of Vedrovice.

Furthermore, Smrčka et al. (2005) have noted the presence of individuals buried at the adjacent settlement site whose $\mathrm{Sr}$ ratios point to nonlocal origins (child aged 6-7 years, Grave 3/1966, and child 
aged 7-8 years, Grave 4/1969), as well as individuals whose strontium values suggest that they might have moved more than once during their lifetime (child aged 5-6 years, Grave 5/I97I, and male aged 40-50 years, Grave 10/1974).

\section{Discussion}

\section{Using isotopic studies to detect migration/mobility}

As noted at the outset of this paper, the data presented here represent one part of a much wider-ranging study aimed at understanding the biosocial aspects of earlier LBK communities. Within this research agenda, humans are recognised as being both biological organisms and social creatures; the research emphasises the interaction between these two aspects of the human condition (Bush and Zvelebil, I991; Meiklejohn and Zvelebil, I99I; Larsen, I997; Eriksson, 2003; Zvelebil and Pettit, 2008).

As there are around 300 known burials for the Moravian LBK, it is apparent that they represent an important resource, given that the number of burials declined through the LBK as cremation rose in importance. Cremation becomes a standard form of burial in the succeeding Middle and Late Neolithic (only eight inhumations are known for the Stroke-Ornamented Pottery culture and 40 for the Moravian Painted Ware [Lengyel] Culture [Dočkalová and Čižmář, 2008]), resulting in a paucity of inhumation burials for study. Although flexed burial was the norm in the Moravian LBK, several forms of mortuary disposal were involved, including the following: inhumation in cemeteries associated with small hamlets, group inhumations within settlements, group inhumations outside settlements, single inhumations within settlements, inhumations within house structures, inhumations bearing traces of violence, and the recovery of disarticulated skeletal parts.

In relation to the designation 'pioneer', we sought to establish precisely how many individuals could be identified as being nonlocal, and thereby potentially influential in the social interactions, and intergenerational transmission of knowledge that is intimately tied up with the integration/adoption of agriculture within the region. The results from the analyses in the sulphur and strontium studies suggest that whilst the majority of the population of Vedrovice remained indigenous to the study region, at least five individuals who spent at least a part of their adult lives in different locations (sulphur isotopes) and three (perhaps four) individuals who were either born elsewhere, or who spent a portion of their childhood elsewehere (strontium isotopes), are interred in the cemetery population (Table I). Only one of the individuals studied was shown by both methods to be of nonlocal birth/residence (individual 79/79), thus we potentially have at least 4 males and 3 females who were not lifelong inhabitants of Vedrovice (Fig. 3).

On the basis of the sulphur and strontium analysis it appears that individual 79/79, an adult male, appears have spent much of his childhood and adulthood away from the Vedrovice area, possibly in coastal regions where marine resources were utilised. The only individual who is perhaps difficult to determine within this stage of the analysis is individual $38 / 76$, whose isotope ratio is close to the main Vedrovice cluster. Moreover, as mentioned in the end of the previous section, Smrčka and colleagues (2005), reporting on their analysis of the individual buried in the settlement, note that 2 children were nonlocal, while one child and one adult male may have moved on more than one occasion during their lifetimes.

Richards and colleagues (2008) report that individuals 51/77, 79/79 and possibly individual 38/76 at Vedrovice exhibit strontium signatures that are consistent with European lowland loess regions 

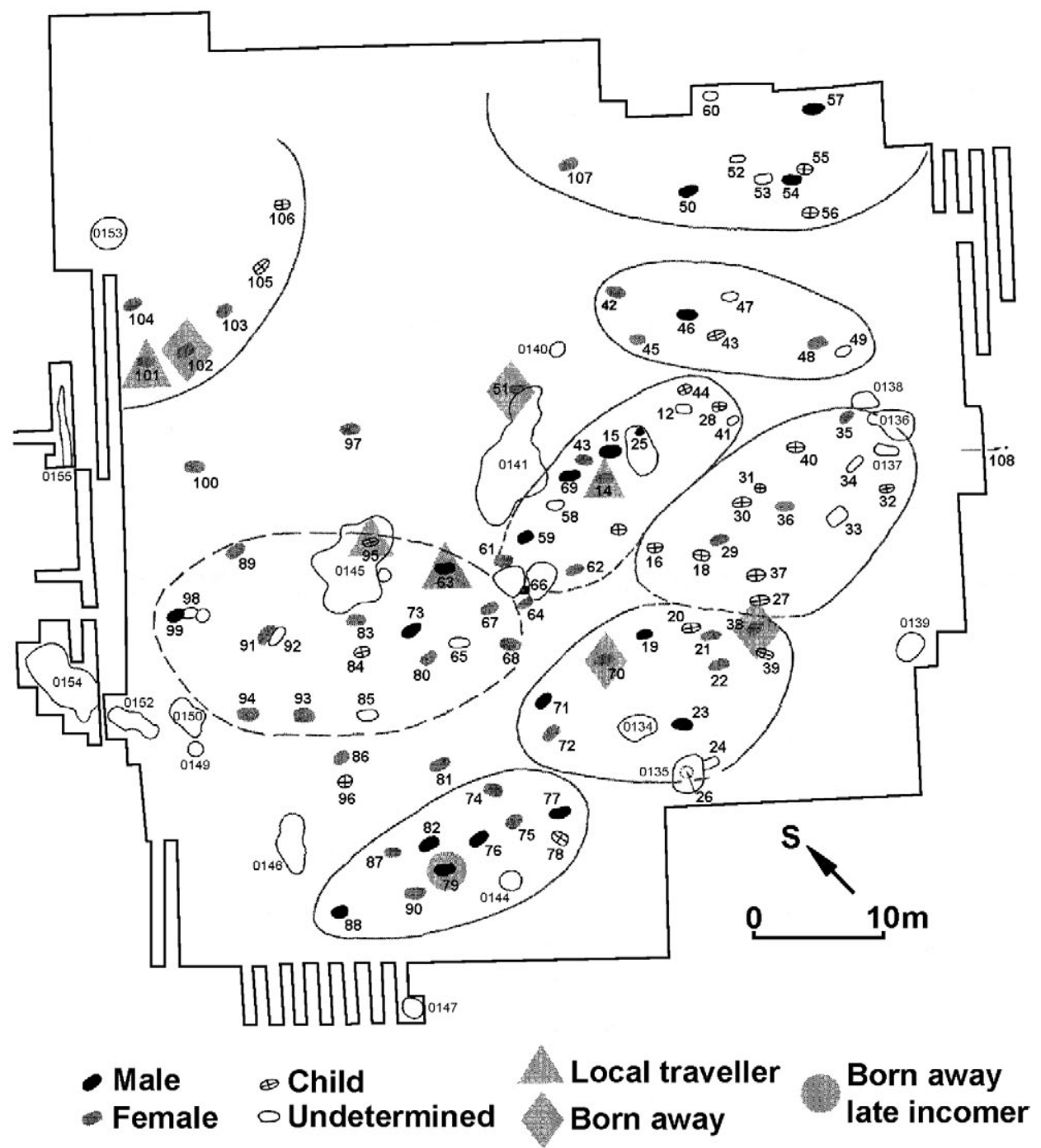

Fig. 3 | Grave clusters within the Vedrovice cemetery indicating internal structuring. Based on Ondruš in Podborský (2002) with alterations and additions by authors based on new analyses

(e.g., Gallet et al., I998, Price et al., 200I, 2004). The average bone strontium value obtained from the sites closest to Vedrovice, Alicenhof in Austria and Moravská Nová Ves in the Czech Republic, is 0.7Io4 (Price et al., 2004) which is lower than the average of 0.7IIo obtained from the enamel samples at Vedrovice but consistent with individual $38 / 76$. The lower strontium ranges obtained for other loess-based sites in Europe suggests that there is an enhanced contribution from Precambrian and Paleozoic rocks to the loess in the vicinity of Vedrovice, which may reflect its position on the edge of the Bohemian Massif. Consequently, it should be possible to identify immigrants to the site from the regions of Tertiary and Quaternary geology to the east and south of Vedrovice, such as the Hungarian Plain, where lower biosphere strontium ratios, such as those obtained from individuals 51/77, 79/79, are found (Giblin, 2005; Price et al., 2004).

The sulphur and strontium analyses have shown that the isotopic values of most of the individuals at Vedrovice suggest that they probably spent all, or the majority, of their lives at or near Vedrovice. How- 
Table 2 | Comparison of individuals in terms of local or exotic habitation, based on strontium (start of life) and sulphur (later life) isotopes (Richards et al., 2008; Smrčka et al., 2008). Where only strontium (Sr) or sulphur (S) measurements are known for a specific individual we make the default assumption that individuals are local in the missing dimension (following Zvelebil and Pettitt, 2008)

\begin{tabular}{|c|c|c|}
\hline & Later life: local resident & Later life: local travellers \\
\hline $\begin{array}{l}\text { Start of life: } \\
\text { locally born }\end{array}$ & $\begin{array}{l}\text { adult males I5/75, 23/75 (S only*), 25/75 (S only), 50/77 } \\
\text { (S only), 54/78, 57/78 (S only), 59/78 (Sr only), 66/70 } \\
\text { (Sr only), 7I/79 (S only), 73/79, 77/79 (S only), 82/79, } \\
\text { 95/80 (S only), 99/8I, Io8/84 (S only), adult females } \\
\text { I3/75 (S only), 38/76 (S only), 42/77, 48/75, 62/78, } \\
\text { 64/78, 72/79 (S only), 75/79, 80/79, 86/78 (S only), } \\
\text { 86/80 (S only), 87/80 (S only), 91/80 (S only), 93a/80, } \\
\text { 97/80 (S only), I00/8I (S only), I04/8I, Io7/82, un- } \\
\text { sexed adults 89/80 (S only), 90/80 (S only), 96/80 } \\
\text { (S only), children I6/75, I7/75 (S only: high sulphur } \\
\text { probably due to breastfeeding/development), 28/76 } \\
\text { (S only), 30/76, 3I/76 (S only), 39/80, 43/77, 44/77 } \\
\text { (S only), 56/78 (S only), 8Ib/79 (newborn), 84/80, } \\
\text { I05/8I, Io6/82 (S only) (n=48) }\end{array}$ & $\begin{array}{l}\text { adult females I4/75 (S only) and } \\
\text { IoI/8I (S only), adult male } 63 / 78 \\
\text { (S only) and very old male } 95 / 80 \\
(\mathbf{n}=4)\end{array}$ \\
\hline $\begin{array}{l}\text { Start of life: exotic: } \\
\text { born elsewhere }\end{array}$ & $\begin{array}{l}\text { adult females } 38 / 76 \text { (Sr only), 5I/77 (Sr only), IO2/8I, } \\
70 / 79(\mathbf{n}=4)\end{array}$ & $\begin{array}{l}\text { adult male } 79 / 79 \text {, adult female } \\
(5 \mathrm{I} / 77) ?(\mathbf{n}=\mathbf{I})\end{array}$ \\
\hline
\end{tabular}

* Where only strontium (Sr) or sulphur (S) measurements are known for a specific individual we make the default assumption that individuals are local in the missing dimension (after Zvelebil and Pettitt, 2008)

ever, there appear to be a few individuals who lived elsewhere as children or adults. Specifically, three adult males and two adult females had sulphur isotope values indicating that they had lived elsewhere within the period preceding their deaths (i.e. over the last Io to 20 years of life), and two males and two adult females had strontium isotope values indicating that they lived elsewhere as children.

The male adult (79/79), whose sulphur and strontium values differed from those of the rest of the population, indicating that he had lived elsewhere both as a child and in the period preceding his death, and who thus must have been a recent immigrant to Vedrovice, was buried with one of the richest grave goods assemblages in the cemetery. This assemblage included a shoe-last adze; a bowl; imported Polish flint blade fragments, possibly indicative of a hunter's status; boar tusk and a Spondylus pendant (Zvelebil and Pettitt, 2008).

The results of our studies to date suggest that a small but significant percentage of the Vedrovice community (about I०\%) were exotic to the settlement and originated in/or interacted with areas at all points of the compass. This includes upland areas to the north, west and east and the Danube basin to the south. There have been archeological findings that suggest that at this point of time the upland areas would still have been supporting Mesolithic hunter-gatherer communities (see Pavlü, 2005; Lukes and Zvelebil, 2006; more broadly, Gronenborn, 2003; Svoboda, 2003; but cf. Vencl and Fridrich, 2007). This is difficult to confirm on chronological grounds give the paucity of dateable archaeological evidence, but given the lack of early Neolithic settlement in these areas we suspect that derivation from or interaction with hunter-gatherers is highly likely. However, the evidence presented here clearly indicates that both males and females were mobile into and out of the Vedrovice area. 


\section{Life biographies}

As part of the main research agenda we have considered the individual life histories of a number of the individuals interred at Vedrovice (Zvelebil and Pettitt, 2008). The memory and meaning that is intertwined with burial practice and patterns of behaviour at Vedrovice allows us to generate insights into the individual, mediated, and shared identities of the people who were born, lived, emigrated and immigrated to the region during the life of the settlement/cemetery, whose knowledge and experience would have informed, modified and influenced social interactions at Vedrovice.

Of the individuals identified as having spent part of their adult life in different locations, or those that spent a portion of their childhood elsewhere (Table 2; Fig. 3), the following three individuals have been studied in some detail.

Individual 79/79: This relatively healthy individual was a late incomer into the Vedrovice community, who was born and spent the last IO-20 years of his life in coastal regions utilising marine resources. Given that his age at death was about 30 years, and considering trace elemental indicators, a coastal location in south-eastern Europe seems the best option as the place of this individual's birth, childhood and adult life. Yet he ended up buried at Vedrovice, and his grave is one of the richest in the community. His head was covered in red ochre. Two pots, a boar tusk, and six flint blades - two made from an imported Polish flint - were placed around his head, while a perforated spondylus pendant was placed into his left palm, and two Krakow (Polish) flint blades and a shoe-last adze were placed along the body. So, although a newcomer to the Vedrovice community, he received respect and achieved a high social status, indicated by the presence of imported flint tools, shoe-last adze and spondylus. Was he a lifelong traveller maintaining contact between communities of different traditions (LBK and, in this case, Vinča), facilitating the transfer of knowledge, information and exchange of goods?

Individual 5I/77: This woman falls into the same category as the man 79/79 in terms of her travels and possibly of birthplace. Both have a strontium profile suggesting marine diet and coastal environment, probably somewhere in southeast Europe. Were they partners (or closely related) in their life and travels? She lived to around 50 years of age, having led a relatively healthy life, with no significant pathologies recorded. Her grave was disturbed by a later Neolithic feature (Moravian Painted Ware) so we cannot be sure of the full range of her grave goods; certainly fragments from two pottery vessels were found in the undisturbed part of the grave.

Individual I02/8I: This woman died as a mature individual aged $40-45$ between 5300 and $5040 \mathrm{BC}$ (with the time of death being most probably in the $53^{\text {rd }}$ century BC according to analysis undertaken by Pettitt and Hedges (2008)). Despite her relatively advanced age, she appears to have been relatively healthy: no pathology was recorded on the postcranial skeleton, the molars show heavy traces of wear normal for her age, but no other pathologies. She was born in an area to the north or northwest of Vedrovice, in the uplands of the Bohemian Massif, where older regions of geology, granites or gneiss, generate a specific strontium signature. She might have joined the Vedrovice community in young adulthood, coming either from the last hunter-gatherer communities living in the uplands of that area, or from the first farming settlements that were just becoming established in eastern Bohemia. Though buried oriented to the east-southeast, she was laid, unconventionally, on her right side, arms flexed, hands folded. She was, then, part of the group of individuals interred at Vedrovice who had links to regions of Bohemia to the northwest. A double perforated spondylus pendant was placed around her waist or hip, and her head was covered by red ochre. The lack of ceramics combined with a state of health which was free of dietary stressors associated with farming is thought-provoking: was she born a hunter- 
gatherer who turned farmer upon joining the Vedrovice community? Her liminal identity is symbolised by the exclusion of ceramics: ceramics being the most standard in the range of grave goods typical for a Vedrovice female.

These individuals highlight the fact that there is evidence at Vedrovice, a community that existed at the earlier part of the LBK cultural development, to suggest that ca. Io \% of the population were immigrants to a community that was indigenous to the region. As the origin, emergence, and dispersal of this cultural tradition have been much debated subjects in the archaeology of the Neolithic and in reconstructions of events that led to the formation of Neolithic Europe, the insights afforded by a multidisciplinary approach to the study of the settlement and cemetery sites at Vedrovice have proven invaluable. In the Conclusions section we consider the significance of the data we have generated.

\section{Conclusions}

For some time now the LBK has been viewed as a classical case of demic diffusion, a migration of entire farming communities from Southeast Europe into Central Europe in the first instance; and then beyond into Western Europe and the North European plain (see Childe, 1925, I957; Ammerman and CavalliSforza, I984; Ammerman and Biagi, 2003; Gkiasta et al., 2002; cf. Gronenborn, 2007; for a critique of this Anglo/American-centric position).

More recently the debate has shifted, with the proposal and discussion by various authors of alternative forms of the origin and dispersal of the LBK, involving a major genetic and cultural contribution to the formation of the LBK by local hunter-gatherer communities of the Mesolithic (e.g. Tillmann, I993; Gronenborn, I999, 2003, 2007; Zvelebil, 2000b, 2004, 2005; Lukes and Zvelebil, 2004; Whittle, I996). The fact that the question has not been resolved through the consideration of LBK groups at the community or population level has obscured the fine detail of socio-cultural interactions at this pivotal time in the formation of Neolithic Europe.

Summarizing the results of our bioarchaeological research at Vedrovice, we envisage a settlement of first farmers in southern Moravia that also served as a gateway community both in terms of incoming individuals and, we would like to argue, individuals leaving to begin other early farming communities. It is possible that Vedrovice was founded by a small community of incomers, founders who would probably have originated in western Hungary towards the end of the formative phase of the LBK (Phase Ia/Ib) some time before 5300 BC.

Soon after Vedrovice was founded, it began attracting people from hunting-gathering communities within the region and outside it. It is at this point or shortly after, at around 5300 BC, that the Siroká u Lesa cemetery was founded to serve the Vedrovice community, upslope from the settlement. The burial here of incomers who had been born elsewhere shows the increasingly cosmopolitan nature of the settlement, where women, in particular, seem to have joined the society from outside. Judging by their material cultural associations, and in one case by biochemical analysis, these immigrants seem for the most part to have come from the region of the Bohemian-Moravian uplands and from northeast Bohemia.

Vedrovice also served as a focal point of a far-flung contact network that facilitated the exchange of goods and information. This included regions located at a considerable distance from southern Moravia, notably southern Poland, northern Bohemia, western Hungary, and coastal south-eastern Europe. These connections are evident in the material culture, which utilized resources from those areas, such as the spondylus ornaments, southern Polish flint, Hungarian radiolarite, or schist/amphibolite from 
northern Bohemia (Zvelebil and Pettitt, 2008). It is also made evident by the burial of "travellers" in the cemetery - people that had spent much of their adult life away from Vedrovice but ended up buried there - and in one case, by the presence of a man who was both born elsewhere and who had lived most of his adult life away from the settlement. In most cases, these people had gained high social status and were buried accordingly. The importance of these individuals in facilitating exchange of information and transmission of knowledge, as well as in contributing to the overall cultural coherence of the LBK tradition as a social phenomenon, cannot be overestimated.

Our research to date has, we believe, facilitated the development of a more holistic understanding of the meanings embedded in material culture, burial and social interactions at the start of the LBK. Our assessment of the ways in which memory and meaning are integral to the processes of cultural transmission, the intergenerational passage of knowledge and reception of information through contact during these formative stages of the LBK have expanded our understanding of the role that immigration, emigration and 'travelling' play in individual life histories. It is no longer acceptable to classify the LBK within a normative paradigm, for, as Zvelebil and Pettitt (2008) emphasize, "we ... now understand that archaeological cultures were the taphonomically sorted, observable end results of socially structured cultural transmission processes, and [the product] of their transformations through [both] individual and collective agency and routine practice".

\section{Acknowledgements}

The research discussed in this paper is the result of an international collaborative partnership between the following institutions: University of Sheffield; Anthropos Institute of the Moravské zemské Museum in Brno; researchers from the Czech Republic (Anthropos Institute and Charles University); Germany (Mainz University, Max Planck Institute for Evolutionary Anthropology, Leipzig) and the United Kingdom (Hull University, Bradford University, Oxford University). It was originally funded by a grant from the Arts and Humanities Research Council (B/RG/ANi85/APNi8452).

Annette Weiske and Stephanie Bösel are thanked for their assistance with the isotopic measurements.

\section{References}

Ammerman, A.J., Cavalli-Sforza, L.L., I984. The Neolithic Transition and the Genetics of Population in Europe. University Press, Princeton.

Ammerman, A.J., Biagi P. (Eds.), 2003. The Widening Harvest. Archaeological Institute of America, Boston.

Bánffy, E., 2004. Advances in the research of the Neolithic transition in the Carpathian Basin, in: Lukes, A., Zvelebil M. (Eds.), LBK Dialogues: Studies in the Formation of the Linear Pottery Culture. British Archaeological Reports International Series 1304, Archaeopress, Oxford, pp. 49-70.

Barker, G., I985. Prehistoric Farming in Europe. Cambridge University Press, Cambridge.
Barrett, J.C., I994. Fragments from Antiquity: An Archaeology of Social Life in Britain 2900-I200 BC. Blackwell, Oxford.

Barrett, J.C., I997. Stone age ideologies. Analecta praehistorica Leidensia 29, I2I-I29.

Bentley, R.A., Knipper, C., 2005. Geographical patterns in biologically available strontium, carbon and oxygen isotope signatures in Prehistoric SW Germany. Archaeometry 47 (3), 629-644.

Berkovec, T., 2003. Plastika na sídlišti kultury s lineární keramikou ve Vedrovicích (okr. Znojmo). Ročenka 2003, Archeologické centrum Olomouc, Olomouc, 46-62. 
Berkovec, T., Veselá B., 2003-4. Pece na sídlišti kultury s lineární keramikou ve Vedrovicích. Sborník Prací Filosofické Fakulty Masarykovi Univerzity-Řada Archaeologická M8-9, 7-30.

Berkovec, T., Dreslerová, G., Nývlotova-Fišáková, M., Švédová J., 2004. Bone industry of the Linear Pottery Culture (LBK) at Vedrovice, Moravia, in: Lukes, A., Zvelebil, M. (Eds.), LBK Dialogues: Studies in the Formation of the Linear Pottery Culture. British Archaeological Reports International Series 1304, Archaeopress, Oxford, pp. I59-I76.

Bourdieu, P., I977. Outline of a Theory of Practice. University Press, Cambridge.

Bourdieu, P., I990. The Logic of Practice. Polity Press, Cambridge.

Budd, P., Montgomery, J., Barreiro, B., Thomas, R.G., 2000. Differential diagenesis of strontium in archaeological human dental tissues. Applied Geochemistry I5 (5), 687-694.

Bush, H., Zvelebil, M. (Eds.), I991. Health in Past Societies: Biocultural Interpretations of Human Skeletal Remains in Archaeological Contexts. British Archaeological Reports, International Series 567. Tempus Reparatum, Oxford.

Cavalli-Sforza, L.L., Cavalli-Sforza, F., I995. The Great Human Diasporas: The History of Diversity and Evolution. Addison-Wesley, New York.

Chapman, J., I994. The origins of farming in South East Europe. Prehistoire Européenne 6, I33-I56.

Childe, V.G., I957. The Dawn of European Civilisation. $6^{\text {th }}$ ed. Routledge and Kegan Paul, London.

Čižmář, Z. 2002. Keramika z pohřebištěŠiroká u Lesa, in: Podborský, V. (Ed.) Dvě pohřebiště neolitického lidu s lineární keramikou ve Vedrovicích na Moravě. Ústav Archeologie a Muzeologie Filozofické Fakulty Masarykovy Univerzity, Brno, pp. I5I-I9O.

Copeland, S.R., Sponheimer, M., Lee-Thorpe, J.A., Le Roux, P.J., Grimes, V., De Ruiter, D.J., Richards, M.P., 2008 . Strontium isotope ratios $(87 \mathrm{Sr} / 86 \mathrm{Sr})$ of tooth enamel: A comparison of solution and laser ablation MCICPMS methods. Rapid Communications in Mass Spectrometry 22 (3), I87-I94.

Crubézy, E., Murail, P., Bruzek, J., Jelinek, J., Ondruš, J., Pavuk, J., Teschler-Nicola, M., I997. Sample characterisation of Danubian cemeteries in central Europe: the examples of Vedrovice (Moravia) and Nitra-Horne Krskany (Slovakia), in: Le Néolithique danubien est ses marges entre rhin et seine. Actes du $22^{\mathrm{e}}$ colloque interrégional sur le Néolithique. Cahiers de l'Association pour la Promotion de la Recherche Archéologique en Alsace, pp. 9-I5.

Dennell, R. I983. European Economic Prehistory. Academic Press, London.
Dobres, M.A., Robb, J.E., 2000. Agency in archaeology: paradigm or platitude, in: Dobres, M.A., Robb, J.E. (Eds.) Agency in Archaeology. Routledge, London, pp. 3-I7.

Dočkalová, M., Čižmář, Z., 2008. Neolithic settlement burials of adult and juvenile individuals in Moravia, Czech Republic. Anthropologie 46 (I), 29-68.

Eriksson, G. (Ed.), 2003. Norm and Difference. Stone Age dietary practice in the Baltic Region. Archaeological Research Laboratory, Stockholm.

Evans, J.A., Tatham, S., 2004. Defining "local signature" in terms of $\mathrm{Sr}$ isotope composition using a tenth-twelfth century Anglo-Saxon population living on a Jurassic clay-carbonate terrain, Rutland, UK, in. Pye, K., Croft, D.J. (Eds.), Forensic Geoscience: Principles, Techniques and Applications. Geological Society of London Special Publication, London, pp. $237-248$.

Gallet, S., Jahn, B.M., Lanoe, B.V., Dia, A., Rossello, E., I998. Loess geochemistry and its implications for particle origin and composition of the upper continental crust. Earth and Planetary Science Letters 156 (3-4), I57-I72.

Giblin, J., 2005. Strontium isotope and trace element analysis of Copper Age human skeletal material from the Great Hungarian Plain. PhD dissertation. Florida State University.

Giddens, A., I979. Central Problems in Social Theory: Action, Structure and Contradiction in Social Analysis. Macmillan, London.

Giddens, A., I984. The Constitution of Society: Outline of the Theory of Structuration. Polity Press, Cambridge.

Gkiasta, M., Russel, T., Shennan, S., Steele, J., 2002. Neolithic transition in Europe: the radiocarbon record revisited. Antiquity 77 (295), 45-62.

Gronenborn, D., I999. A variation on a basic theme: the transition to farming in southern Central Europe. Journal of World Prehistory I3 (2), I23-209.

Gronenborn, D., 2003. Migration, acculturation, and culture change in western temperate Eurasia, 65005000 cal BC. Documenta praehistorica 30, 79-91.

Gronenborn, D., 2004. Comparing contact-period archaeologies: the expansion of farming and pastoralist societies to continental temperate Europe and to southern Africa. Before Farming [Online Version] 2004 (4), Article 3, I-35.

Gronenborn, D., 2007. Beyond the models: "Neolithisation" in Central Europe. Proceedings of the British Academy I44, 73-98.

Hodder, I., I992. Theory and Practice in Archaeology. Routledge, London. 
Hodder, I., 2000. Agency and individuals in long-term processes, in: Dobres, M.A., Robb, J.E. (Eds.), Agency in Archaeology. Routledge, London, pp. 2I-33.

Hoppe, K.A., Koch, P.L., Furutani, T.T., 2003. Assessing the preservation of biogenic strontium in fossil bones and tooth enamel. International Journal of Osteoarchaeology 13, 20-28.

Humpolová, A., 200I. Rondeloid číslo III lidu s Moravskou malovanou keramikou ve Vedrovicích, in: Podborský, V. (Ed.), 50 let archeologických výzkumů Masarykovy univerzity na Znojemsku. Ústav archeologie a muzeologie filosofická fakulta Masarykovy univerzity, Brno, pp. I57-166.

Humpolová, A., Ondruš, V., I999. Vedrovice, okres Znojmo, in: Podborský, V. (Ed.) Pravěká sociokulturní architektura na Moravě. Ústav archeologie a muzeologie filosofická fakulta Masarykovy univerzity, Brno, pp. I67-2I9.

Larsen, C.S., I997. Bioarchaeology: Interpreting Behavior from the Human Skeleton. University Press, Cambridge.

Lillie, M.C., 2008. Vedrovice: demography and palaeopathology in an early farming population. Anthropologie XLVI (I-2), I35-I52.

Lukes, A., 2004. Social perspectives on the constitution of the Linear pottery culture (LBK), in: Lukes, A., Zvelebil, M. (Eds.), LBK Dialogues: Studies in the Formation of the Linear Pottery Culture. British Archaeological Reports International Series I304, Archaeopress, Oxford, pp. I7-33.

Lukes, A., 2006. The Constitution of the Czech LBK Culture: A Social Perspective. PhD thesis, University of Sheffield, Sheffield.

Lukes, A., Zvelebil, M. (Eds.), 2004. LBK Dialogues: Studies in the Formation of the Linear Pottery Culture. British Archaeological Reports International Series 1304, Archaeopress, Oxford.

Lukes, A., Zvelebil, M., 2006. Inter-generational transmission of culture and LBK origins, some indications from eastern-central Europe, in: Bailey, D., Whittle, A., Hofmann, D. (Eds.), Living Well Together? Settlement and Materiality in the Neolithic of South-East and Central Europe. Oxbow Books, Oxford, pp. I39-I50.

Lukes, A., Zvelebil, M., Petitt, P., 2008. Biological and cultural identity of the first farmers: Introduction to the Vedrovice Bioarchaeology Project. Anthropologie XLVI (I-2), II7-I24.

Lüning, J., I988. Frühe Bauern in Mitteleuropa im 6. und 5. Jahrtausend v. Chr. Jahrbuch des Römisch-Germanischen Zentralmuseums 35 (I), 27-93.

Mateiciucová, I., 2004. Mesolithic traditions and the origin of the Linear pottery culture (LBK), in: Lukes, A.,
Zvelebil, M. (Eds.), LBK Dialogues. Studies in the Formation of the Linear Pottery Culture. British Archaeological Reports International Series I304, Archaeopress, Oxford, pp. 9I-IO7.

McArthur, J.M., Howarth, R.J., Bailey, T.R., $200 \mathrm{I}$. Strontium isotope stratigraphy: LOWESS version 3: best fit to the marine Sr-isotope curve for 0-509 Ma and accompanying look-up table for deriving numerical age. Journal of Geology Iog (2), I55-I70.

Meiklejohn, C., Zvelebil, M., I99I. Health status of European populations at the agricultural transition and the implications for the adoption of farming, in: Bush, H., Zvelebil, M. (Eds.), Health in Past Societies: Biocultural Interpretations of Human Skeletal Remains in Archaeological Contexts. British Archaeological Reports (International Series) 567, Tempus Reparatum, Oxford, pp. I29-I45.

Modderman, P.J.R., I988. The Linear Pottery culture: diversity in uniformity. Berichten van de rijksdienst voor het outheidkundig bodemonderzoek 38, 63-139.

Montgomery, J., 2002. Lead and strontium isotope compositions of human dental tissues as an indicator of ancient exposure and population dynamics. PhD dissertation, University of Bradford.

Montgomery, J., Evans, J.A., Powlesland, D. and Roberts, C.A., 2005. Continuity or colonization in AngloSaxon England? Isotope evidence for mobility, subsistence practice, and status at West Heslerton. American Journal of Physical Anthropology I26 (2):I23-I38.

Montgomery, J., Evans, J.A., Cooper. R.E., 2007. Resolving archaeological populations with Sr-isotope mixing models. Applied Geochemistry 22 (7), I5O2-I5I4.

Ondruš, V., 2002. Dvě pohřebiště Lidu s Neolitickou lineární keramikou ve Vedrovicích, in: Podborský, V. (Ed.), Dvě pohřebiště Neolitického lidu s lineární keramikou ve Vedrovicích na Moravě. Ústav archeologie a muzeologie filosofická fakulta Masarykovy univerzity, Brno, pp. 9-I22.

Pavlů, I., 2005. Neolitizace Evropy. Archeologické rozhledy 57, 293-302.

Pettitt, P., Hedges, R.E.M., 2008. The age of the Vedrovice cemetery: the AMS radiocarbon dating programme. Anthropologie XLVI (2-3), I25-34.

Piggott, S., I965. Ancient Europe. Edinburgh University Press, Edinburgh.

Pluciennik, M., I998. Deconstructing 'the Neolithic' in the Mesolithic-Neolithic transition, in: Edmonds, M.R., Richards, C. (Eds.), Understanding the Neolithic of North-Western Europe. Routledge, London, pp. 6I-83.

Podborský, V. (Ed.), I993. Pravěké dějiny Moravy. Muzejní a Vlastivědná Společnost v Brně, Brno. 
Podborský, V. (Ed.), 2002. Dvě pohřebiště Neolitického lidu s lineární keramikou ve Vedrovicích na Moravě. Ústav archeologie a muzeologie filosofické fakulty Masarykovy univerzity, Brno.

Price, T.D., I987. The Mesolithic in Western Europe. Journal of World Prehistory I, 225-332.

Price, T.D., 2000. Europe's first farmers: an introduction, in: Price, T.D. (Ed.), Europe's First Farmers. University Press, Cambridge, pp. I-I8.

Price, T.D., Bentley, R.A., Lüning, J., Gronenborn, D., Wahl, J., 200I. Prehistoric human migration in the Linearbandkeramik of Central Europe. Antiquity 75 (289), 593-603.

Price, T.D., Burton, J.H., Bentley, R.A., 2002. The characterization of biologically available strontium isotope ratios for the study of prehistoric migration. Archaeometry 44 (I), II7-I35.

Price, T.D., Knipper, C., Grupe, G., Smrčka, V., 2004. Strontium isotopes and prehistoric human migration: the Bell Beaker Period in Central Europe. European Journal of Archaeology 7 (I), 9-40.

Prohaska, T., Latkoczy, C., Schultheir, G., TeschlerNicola, M., Stingeder, G., 2002. Investigation of Sr isotope ratios in prehistoric human bones and teeth using laser ablation ICP-MS after $\mathrm{Rb} / \mathrm{Sr}$ separation. Journal of Analytical Atomic Spectrometry I7 (8), 887-89I.

Renfrew, C., I996. Prehistory and identity of Europe, or don't let's be beastly to the Hungarians, in: GravesBrown, P. Jones, S., Gamble, C. (Eds.), Identity and Archaeology. The Construction of European Communities. Routledge, London.

Richards, M.P., Fuller, B.F., Hedges, R.E.M., 200I. Sulphur isotopic variation in ancient bone collagen from Europe: Implications for human palaeodiet, residence mobility, and modern pollutant studies. Earth and Planetary Science Letters I9I, I85-I9O.

Richards, M.P., Fuller, B.T., Sponheimer, M., Robinson, T., Ayliffe, L., 2003. Sulphur isotope measurements in archaeological samples: some methodological considerations. International Journal of Osteoarchaeology I3, 37-45.

Richards, M.P., Montgomery, J., Nehlich, O., Grimes, V., 2008. Isotopic analysis of humans and animals from Vedrovice. Anthropologie XLVI (I-2), I85-I94.

Rulf, J., I995. Provinces, regions and sub-regions: the Labe/Elbe group of Linear Pottery Culture example, in: Kuna, M., Venclová, N. (Eds.), Whither Archaeology? Papers in Honour of Evžen Neustupný. Institute of Archaeology, Prague, pp. 299-3I2.

Rulf, J., I997. Die Elbe-Provinz der Linearbandkeramik. Památky archeologické, supplementum 9. Archeologický Ústav, Prague.
Schutkowski, H., 2002. Mines, meals and movement: a human ecological approach to the interface of 'history and biology', in: Smith, M. (Ed.), Human Biology and History. Society for the Study of Human Biology Series 42. Taylor and Francis, London, pp. I95-202.

Shanks, M., Tilley, C., I992. Re-Constructing Archaeology: Theory and Practice. $2^{\text {nd }}$ ed. Routledge, London.

Smrčka, V., Bůzek, F., Erban, V., Berkovec, T., Dočkalová, M., Neumanová, K., Fišáková, M.N., 2005. Carbon, nitrogen and strontium isotopes in the set of skeletons from the Neolithic settlement at Vedrovice (Czech Republic). Anthropologie (Brno) XLIII (2-3), 3I5-323.

Smrčka, V., Mihaljevič, M., Zocová, J., Šebek, O., Humpolova, A., Berkovec, T., Dočkalová, M., 2008. Traceelemental analysis of skeletal remains of humans and animals at the Neolithic settlement in Vedrovice (Czech Republic). Anthropologie (Brno) XLVI (2-3), 2I9-226. Svoboda, J. (Ed.), 2003. Mezolit Severních Čech. Brno. Tilley, C., I994. A Phenomenology of Landscape: Places, Paths and Monuments. Berg, Oxford.

Tillmann, A., I993. Kontinuität oder Diskontinuität? Zur Frage einer bandkeramischen Landnahme im südlichen Mittleleuropa. Archäologische Informationen I6 (2), I57-I87.

Trickett, M.A., Budd, P., Montgomery, J., Evans, J., 2003. An assessment of solubility profiling as a decontamination procedure for the Sr-87/Sr-86 analysis of archaeological human skeletal tissue. Applied Geochemistry I8 (5), 653-658.

Van Andel, T.H., Runnels, C.N., I995. The earliest farmers in Europe. Antiquity 69, 48I-500.

Vencl, S., I986. The role of hunting-gathering populations in the transition to farming: a central European perspective, in: Zvelebil, M. (Ed.), Hunters in Transition: Mesolithic Societies of Temperate Eurasia and their Transition to Farming. University Press, Cambridge. pp. 43-52.

Vencl, S., Fridrich, J., 2007. Archeologie Pravěkých Cech 2. Paleolit a Mezolit. Archeologický ústav AVCR, Prague.

Whittle, A., I996. Europe in the Neolithic: The Creation of New Worlds. University Press, Cambridge.

Zvelebil, M. (Ed.), I986. Hunters in Transition: Mesolithic Societies of Temperate Eurasia and Their Transition to Farming. University Press, Cambridge.

Zvelebil, M., I995. Neolithisation in eastern Europe: a view from the frontier. Poročilo o raziskovanju paleolitika, neolitika in eneolitika v Sloveniji 22, I07-I5O.

Zvelebil, M., I996. The agricultural frontier and the transition to farming in the circum-Baltic region, in: 
Harris, D. (Ed.), The Origins and Spread of Agriculture and Pastoralism in Eurasia. University College London Press, London, pp. 323-345.

Zvelebil, M., 2000a. Les derniers chasseurs-collecteurs d'Europe tempérée, in: Les derniers chasseurs-cuilleurs d'Europe occidentale (I3000-5500 av. J.-C.), Actes du colloque international de Besançon, octobre 1998. Presses Universitaires Franc-Comtoises, Besançon, pp. 379-406.

Zvelebil, M., 200ob. The social context of the agricultural transition in Europe, in: Renfrew, C., Boyle, K. (Eds.), Archaeogenetics: DNA and the population prehistory of Europe. McDonald Institute Monographs, Cambridge, pp. 57-79.

Zvelebil, M., 2004. Who were we 6000 years ago? In search of prehistoric identities, in: Jones, M. (Ed.), The Traces of Ancestry: Studies in Honour of Colin Renfrew. McDonald Institute Monographs, Cambridge, pp. 4I-6o.
Zvelebil, M., 2005. Homo habitus: agency, structure and the transformation of tradition in the constitution of the TRB foraging-farming communities in the North European plain (ca. 4500-2000 BC). Documenta Praehistorica XXXII, 87-IOI.

Zvelebil, M., Pettitt, P., 2008. Human condition, life, and death at an early Neolithic settlement: bioarchaeological analyses of the Vedrovice cemetery and their biosocial implications for the spread of agriculture in Central Europe. Anthropologie (Brno) XLVI (2-3), I95-2I8.

Zvelebil, M., Lukes, A., Pettitt, P., 20Io. The emergence of the LBK culture: Search for the ancestors. in: Gronenborn, D., Petrasch, J. (Eds.), Die Neolithisierung Mitteleuropas [The Spread of the Neolithic to Central Europe]. Verlag des Römisch-Germanischen Zentralmuseums, Mainz, pp. 30I-326. 